\title{
Hubungan pengetahuan perawat instalasi gawat darurat (IRD) dengan kesiapan menghadapi bencana di RSUD Majene
}

\author{
Indrawati ${ }^{1}$, Wardina Sari ${ }^{2}$ \\ 1,2,3. Universitas Sulawesi Barat \\ Email: Indrawati@unsulbar.ac.id
}

\begin{abstract}
Abstrak
Indonesia merupakan salah satu negara rawan bencana dilihat dari aspek geografis, klimatologis dan demogafis. Letak geografis Indonesia di antara dua benua dan dua samudra menyebabkan Indonesia mempunyai potensi bagus dalam perekonomian sekaligus rawan dengan bencana. Kabupaten Majene merupakan salah satu kabupaten yang hampir $40 \%$ dari wilayahnya berada di pesisir pantai. Dan sebagian wilayah yang lain berada di aliran sungai yang keduanya mempunyai potensi bencana seperti Angin kencang, banjir dan tsunami.Penelitian ini bertujuan untuk mengidentifikasi hubungan pengetahuan perawat Instalasi Gawat Darurat dengan kesiapan menghadapi bencana di RSUD Majene. Penelitian ini menggunakan metode Survey analitik dengan desain Cross Sectional. Variabel independen adalah pengetahuan perawat dan variabel dependentnya adalah kesiapsiagan menghadapi bencana di RSUD Majene. Pengambilan sampel menggunakan metode Total Sampling sebanyak 27 orang Perawat di Instalasi Gawat Darurat RSUD Majene. Hasil penelitian menunjukkan Pengetahuan perawat di Instalasi Gawat Darurat Rumah Sakit Umum Majene tentang kesiapsiagaan menghadapi bencana lebih banyak pada kategori kurang Kesiapsiagaan perawat di Instalasi Gawat Darurat Rumah Sakit Umum Majene dalam menghadapi bencana lebih banyak pada kategori kurang. Tidak terdapat Hubungan Pengetahuan perawat Instalasi Gawat Darurat RSUD Majene dengan kesiapan menghadapi bencana di RSUD Majene. Disarankan kepada pihak rumah sakit agar memberikan kesempatan kepada sebagian perawat untuk mengikuti pelatihan - pelatihan khusunya pelatihan tentang kesiapsiagaan menghadapi bencana. Pihak rumah sakit sebaiknya berupaya untuk mengadakan pelatihan tentang kesiapsiagaan menghadapi bencana.
\end{abstract}

Kata kunci : bencana, kesiapsiagaan, gawat darurat, pengetahuan.

\begin{abstract}
Indonesia is one of the disaster-prone countries in terms of geographical, climatological and democratic aspects. Indonesia's geographical position between two continents and two oceans causes Indonesia to have good potential in the economy while at the same time prone to disasters. Majene Regency is one of the districts with almost $40 \%$ of its territory on the coast. And some other areas are in the river which both have the potential for disasters such as strong winds, floods and tsunamis. This study aims to identify the relationship between knowledge of nurses in emergency care and disaster preparedness in the Majene Hospital. This study uses an analytical survey method with Cross Sectional design. The independent variable is nurses' knowledge and the dependent variable is preparedness to deal with disasters in Majene Hospital. Sampling using the total sampling method as many as 27 nurses in the Emergency Department of Majene Hospital. The results showed that the knowledge of nurses in the Emergency Room of the Majene General Hospital regarding disaster preparedness was more in the category of less nurse preparedness in the Emergency Installation of Majene General Hospital in facing more disasters in the less category. There is no correlation between Knowledge of Nurses in the Emergency Department of Majene Hospital and disaster preparedness in Majene Hospital. It is recommended to the hospital to provide an opportunity for some nurses to attend training - especially training on disaster preparedness. The hospital should try to conduct training on disaster preparedness.
\end{abstract}

Keywords : disaster, preparedness, emergency, knowledge. 


\section{Pendahuluan}

Indonesia merupakan salah satu negara rawan bencana dilihat dari aspek geografis, klimatologis dan demografis. Letak geografis Indonesia di antara dua benua dan dua samudra menyebabkan Indonesia mempunyai potensi bagus dalam perekonomian sekaligus rawan dengan bencana. Indonesia merupakan negara yang paling banyak memiliki gunung api di dunia yaitu 500 gunung api yang tersebar di Indonesia dan 129 diantaranya merupakan gunung api aktif, sekitar 70 dari gunung aktif tersebut sering meletus. Berdasarkan sebaran zona resiko tinggi yang ditempatkan dalam indeks rasio bencana letusan gunung api di Indonesia maka Badan Nasional Penanggulangan Bencana telah menyatakan penanggulangan bencana letusan gunung api dalam 5 tahun sejak tahun 2011 diarahkan pada wilayah rawan bencana gunung api (BNPB, 2011).

Sebenarnya Indonesia sangat berpengalaman karena sudah sering daerah-daerah yang mengalami bencana tetapi penanganan pada saat kejadian ternyata kurang baik bahkan nampak tidak siap. Pada pasal 2 Peraturan Pemerintah Nomor 21 Tahun 2008 tentang penyelenggaraan penanggulangan bencana menyatakan bahwa penanggulangan bencana dilaksanakan secara terencana, terpadu, terkoordinasi dan menyeluruh dalam rangka memberikan perlindungan kepada masyarakat dari ancaman, risiko dan dampak bencana. Penanggulangan bencana adalah serangkaian upaya mengurangi resiko bencana meliputi mengurangi resiko terjadinya bencana, kegiatan pencegahan bencana, tanggap darurat dan rehabilitasi (BNPB, 2010).

Kondisi inilah yang mendorong diperlukannya upaya kesiapsiagaan yang terus menerus dilakukan agar apabila terjadi bencana maka semua lini masyarakat dan pemerintah siap dalam penanggulangan dampak bencana. Kesiapsiagaan unsur pemerintah diantaranya adalah tenaga kesehatan di daerah rawan bencana (AWHONN, 2012).

Perawat sebagai bagian terbesar tenaga kesehatan yang berada di daerah mempunyai peran sangat penting karena perawat sebagai lini terdepan pelayanan kesehatan. Masalah utama dalam kesiapsiagaan penanggulangan bencana menurut penelitian yang dilakukan oleh Kija Chapman dan Paul Arbon (2008) menyatakan bahwa pengetahuan perawat masih kurang dalam manajemen bencana meliputi pengetahuan tentang kesiapsiagaan bencana, tanggap bencana dan pemulihan setelah bencana. Perawat kurang baik dalam implementasi dan belum ada standarisasi kesiapsiagaan bencana (Anam, 2013).

Menurut Chapman (2008) menyatakan bahwa $80 \%$ perawat yang menjadi relawan bencana tidak mempunyai pengalaman dalam tanggap bencana serta $23 \%$ perawat hanya pernah mendapatkan pendidikan kesiapsiagaan bencana dasar dan tidak ada pendidikan kelanjutannya. Begitu juga yang dikemukakan oleh Fung (2008) yang menyatakan bahwa sebagian besar perawat $(97 \%)$ tidak mempunyai persiapan yang baik dalam penanganan bencana (Anam, 2013).

Penelitian yang dilakukan oleh Hidayati (2008) menemukan bahwa terdapat hubungan yang signifikan antara pengetahuan perawat IRD dengan kesiapan dalam menghadapi bencana di RSUP DR Sardjito. Dalam penelitian ini ditemukan bahwa $82 \%$ pengetahuan perawat tentang kesiapan menghadapi bencana pada kategori baik. Begitu dengan penelitian yang dilakukan oleh Anam (2013) yang juga menemukan bahwa salah satu faktor yang mempengaruhi kesiapan perawat dalam menghadapi bencana adalah faktor pengetahuan. Pada penelitian ini ditemukan bahwa semakin baik pengetahuan perawat semakin baik pula kesiapan mereka dalam menghadapi bencana. 
Penelitian lain yang juga menemukan hasil yang sama adalah penelitian yang dilakukan oleh Gulton (2012) yang menemukan bahwa pengetahuan dan sikap memperlihatkan hubungan yang signifikan dengan kesiapsiagaan tenaga kesehatan Puskesmas Kampung Baru menghadapi bencana banjir. Begitu juga dengan penelitian yang dilakukan oleh Dodon (2013) salah satu indikator kesiapsiagaan masyarakat dalam menghadapi bencana adalah pengetahuan masyarakat terhadap kesiapsiangaan menghadapi bencana.

Kabupaten Majene merupakan salah satu kabupaten yang hampir $40 \%$ dari wilayahnya berada di pesisir pantai. Dan sebagian wilayah yang lain berada di aliran sungai yang keduanya mempunyai potensi bencana seperti angin kencang, banjir dan tsunami. Hampir setiap tahun daerah pesisir Kabupaten Majene dilanda angin kencang dan banjir. Meskipun sampai sekarang wilayah Kabupaten Majene belum pernah dilanda gempa dengan tsunami, tetapi kesiapan pemerintah dalam menghadapi segala kemungkinan harus tetap dipersiapkan.

Berdasarkan data Badan Penaggulangan Bencana Daerah Kabupaten Majene didapatkan bahwa pada tahun 2012 kejadian bencana banjir pada tahun 2011-2012 yang menewaskan 4 orang dan longsor sebanyak 2 orang. Sedangkan kejadian bencana angin puting beliung dan angin kencang terjadi sebanyak 36 kali pada tahun yang sama. Begitu juga dengan bencana kebakaran sampai terjadi sebanyak 14 kali.

Rumah Sakit Umum Daerah Majene sebagai satu-satunya pusat rujukan pelayanan kesehatan di Kabupaten Majene seharusnya berbenah diri dengan melihat segala kemungkinan yang dapat terjadi. Kejadian bencana merupakan hal yang tidak dapat diprediksikan kapan terjadinya. Sehingga pihak rumah sakit perlu melakukan langkah prepentive untuk menghadapi hal tersebut. Menurut penuturan salah satu staf perawat di RSUD Majene bahwa pihak rumah sakit sudah mempunyai program khusus untuk penanganan bencana bahkan beberapa tahun yang lalu sempat dilaksanakan pelatihan tanggap bencana alam dengan bekerja sama dengan salah satu institusi pendidikan kesehatan setempat.

Berdasarkan data Kepegawaian RSUD Majene tahun 2014-2015, jumlah perawat yang bertugas di ruang IRD RSUD Majene sebanyak 32 orang yang terdiri dari 8 orang PNS dan 24 orang non PNS. Sehubungan dengan fenomena ini, penulis merasa tertarik untuk melakukan penelitian, sehingga pada tahap awal ini untuk mendapatkan data yang akurat dengan pertimbangan jarak serta waktu yang singkat maka penulis akan mengadakan suatu penelitian dengan judul "Hubungan Pengetahuan perawat Instalasi Rawat Darurat dengan kesiapan menghadapi bencana di RSUD Majene tahun 2015”.

\section{Metode}

Penelitian ini merupakan penelitian Survey analitik dengan pendekatan cross sectional dimana hubungan pengetahuan dengan kesiapan menghadapi bencana di lakukan pengukuran atau pengamatan pada saat bersamaan (sekali waktu). Penelitian ini dilaksanakan di ruang IRD RSUD Kabupaten Majene Tahun 2015. Jumlah sampel sebanyak 27 orang.

\section{Hasil}

Distribusi responden berdasarkan umur paling banyak responden berumur 26 - 35 tahun sebanyak 19 responden $(70.4 \%)$, dan paling sedikit pada umur 17 - 25 tahun sebanyak 8 responden (29.6\%). Distribusi responden berdasarkan jenis kelamin, dimana laki-laki sebanyak 6 responden $(22.2 \%)$ dan perempuan sebanyak 21 responden $(77.8 \%)$. Distribusi responden berdasarkan tingkat pendidikan, dimana dalam penelitian ini responden terbanyak adalah berpendidikan Diploma III Keperawatan sebanyak 19 (70.4\%), dan yang paling sedikit adalah D IV 
Keperawatan yaitu 1 responden $(3.7 \%)$. Distribusi responden berdasarkan status kepegawaian dimana responden yang terbanyak adalah tenaga Sukarela sebanyak 21 responden $(77.8 \%)$, dan yang paling sedikit adalah PNS sebanyak 6 responden (22.2\%). Distribusi responden berdasarkan keikutsertaan pelatihan dimana responden yang pernah ikut pelatihan sebanyak 15 responden $(55.6 \%)$ dan yang belum pernah ikut pelatihan tentang kesiapsiagaan menghadapi korban bencana sebanyak 12 orang $(44.4 \%)$.

\section{Analisis Univariat}

Distribusi responden berdasarkan pengetahuan perawat, dimana dalam penelitian ini responden terbanyak adalah pengetahuan kurang sebanyak 18 (66.7\%), dan yang paling sedikit adalah pengetahuan cukup yaitu 9 responden (33.3\%). Distribusi responden berdasarkan Kesiapsiagaan menghadapi bencana, dimana dalam penelitian ini responden terbanyak adalah kategori Kurang sebanyak 16 (59.3\%), dan yang paling sedikit adalah kategori baik yaitu 11 responden $(40.7 \%)$.

\section{Analisis bivariat}

Tabel 1

Hubungan Pengetahuan dengan Kesiapsiagaan Menghadapi Bencana di Instalasi Gawat Darurat RSUD Majene Tahun 2015

\begin{tabular}{|c|c|c|c|c|c|c|c|}
\hline \multirow{2}{*}{ Pengetahuan } & \multicolumn{4}{|c|}{ Kesiapsiagaan } & \multirow{2}{*}{ Total } & \multirow{2}{*}{$\%$} & \multirow{2}{*}{$P$-Value } \\
\hline & \multicolumn{2}{|c|}{ Cukup } & \multicolumn{2}{|c|}{ kurang } & & & \\
\hline Cukup & 2 & $7.4 \%$ & 7 & $25.9 \%$ & 9 & $33.3 \%$ & \\
\hline Kurang & 9 & $33.3 \%$ & 9 & $33.3 \%$ & 18 & $66.7 \%$ & 0,166 \\
\hline Total & 11 & $40.7 \%$ & 16 & $59.3 \%$ & 27 & $100 \%$ & \\
\hline
\end{tabular}

Tabel 1 menggambarkan distribusi responden berdasarkan pengetahuan dan kesiapsiagaan menghadapi bencana, dari 9 orang responden yang berpengetahuan cukup, sebanyak 2 responden $(7.4 \%)$ yang kesiapsiagaan cukup dan 7 orang $(25.9 \%)$ yang kesiapsiagaan kurang. Sedangkan dari 18 orang yang berpengetahuan kurang, terdapat 9 orang (33.3\%) yang kesiapsiagaan cukup dan 9 orang $(33.3 \%)$ yang kesiapsiagaan kurang. Dengan menggunakan uji statistik Fisher Exact diperoleh nilai $\rho=0,166>\alpha=0,05$. Dengan demikian $\mathrm{H} 1$ ditolak yang berarti tidak terdapat Hubungan Pengetahuan perawat IGD dengan kesiapan menghadapi bencana Di RSUD Majene tahun 2015.

\section{Pembahasan}

Berdasarkan hasil penelitian didapatkan bahwa dari 9 orang responden yang berpengetahuan cukup, sebanyak 2 responden (7.4\%) yang kesiapsiagaan cukup dan 7 orang (25.9\%) yang kesiapsiagaan kurang. Sedangkan dari 18 orang yang berpengetahuan kurang, terdapat 9 orang (33.3\%) yang kesiapsiagaan cukup dan 9 orang $(33.3 \%)$ yang kesiapsiagaan kurang. Dengan menggunakan uji statistik Fisher Exact diperoleh nilai $\rho=0,166>\alpha=0,05$. Dengan demikian $\mathrm{H} 1$ ditolak yang berarti tidak terdapat Hubungan Pengetahuan perawat IRD dengan kesiapan menghadapi bencana di RSUD Majene tahun 2015. 
Hasil penelitian menunjukkan bahwa tingkat pengetahuan secara kognitif perawat di IRD RSUD Majene tentang kesiapsiagaan menghadapi bencana lebih banyak pada kategori kurang. Hal ini disebabkan karena baru $55.6 \%$ yang pernah mengikuti pelatihan tentang kesiapsiagaan menghadapi bencana, selain hal tersebut masih adanya faktor faktor yang menyebabkan seperti kurangnya sosialisasi tentang kesiapsiagaan bencana, terbatasnya sarana dan fasilitas di IRD RSUD Majene, kurangnya perencanaan persiapan dalam menghadapi bencana serta tingkat pendidikan perawat di IRD terbanyak yaitu DIII sehingga juga mempengaruhi karena perawat hanya mendapatkan pendidikan kesiapsiagaan bencana dasar di bangku kuliah dan tidak ada pendidikan kelanjutannya, kecuali mengikuti pelatihan/kegiatan tentang kesiapsiagaan bencana. Sehingga presentasi kesiapsiagaan perawat dalam menghadapi bencana juga lebih banyak pada kategori kurang.

Menurut Kusnato (2007), bahwa pada setiap bencana selalu timbul kerugian bagi manusia, yang dapat berupa kerugian materi yaitu hilangnya harta benda, rusaknya tempat tinggal, hilangnya mata pencaharian dan mengakibatkan gangguan badani yang berupa kesakitan bahkan kematian. Keadaan korban bencana yang mengalami kesakitan bahkan kematian, maka yang pertama kali yang dicari oleh korban dan kerabatnya apabila mengalami bencana adalah fasilitas kesehatan. Biasanya korban yang timbul pada keadaan bencana jumlahnya sangat banyak karena sifatnya yang bersifat mendadak, maka apabila tidak dipersiapkan secara baik dapat merepotkan tenaga kesehatan yang ada (Hidayati, 2008).

Apabila pihak rumah sakit dalam hal ini IRD kedatangan pasien korban bencana dalam jumlah yang cukup banyak dalam waktu yang sangat mendadak, maka pihak RS dapat kewalahan dalam melayaninya. Untuk itu dibutuhkan para perawat yang mempunyai pengetahuan yang baik untuk menghadapi hal tersebut. Apalagi wilayah rumah sakit umum Majene merupakan wilayah yang rawan atau sering kali terjadi bencana secara mendadak, maka dibutuhkan para perawat yang selalu siap siaga dalam menghadapi bencana.

Temuan pada penelitan ini menunjukkan bahwa tidak terdapat hubungan yang signifikan antara pengetahuan perawat dengan kesiapsiagaan perawat dalam menghadapi bencana. Hal ini ditunjukkan dengan adanya perawat yang pengetahuannya kurang tentang kesiapsiagaan dalam menghadapi bencana, akan tetapi karena pernah mengikuti pelatihan, maka perawat tersebut dengan mudah memberikan respon jawaban tentang kesiapsigaan dalam menghadapi bencana. Begitupun sebaliknya, terdapat perawat yang pengetahuan kognitifnya tentang kesiapsiagaan menghadapi bencana pada kategori cukup, tetapi dalam kesiapsiagaan masih kurang.

Pada penelitian Lisnawati Nur Farida (2010) tentang Gambaran Kesiapsiagaan Perawat Puskesmas dalam Manajemen Bencana di Puskesmas Kasihan 1 Bantul Yogyakarta diperoleh hasil bahwa kesiapsiagaan perawat di tingkat kecamatan khususnya di puskesmas kasihan 1 bantul masih rendah. Dalam penelitian ini dijelaskan bahwa sebagian besar peran tidak dijalankan sebagaimana mestinya, dikarenakan belum adanya persiapan dari pihak institusi dalam persiapan bencana. Meskipun seluruh responden telah dibekali pelatihan penanganan kegawatdaruratan, tidak adanya perencanaan bencana menjadi faktor penghambat kesiapan perawat dalam merespon bencana.

Penelitian menurut Sarim (2003) tentang Analisis Kesiapan Menghadapi Bencana di Instalasi Rawat Darurat Rumah Sakit Umum Daerah se-Wilayah Pembangunan Cirebon Tahun 2003, Rumah sakit belum 
menunjukkan kesiapan yang baik dalam menanggulangi kegawatdaruratan bencana/sehari hari disebabkan oleh kurangnya dukungan direktur, kurang sosialisasi serta kurangnya dukungan sumber daya.

Penelitian lain juga dilakukan oleh Ismunandar (2012) tentang Kesiapan Rumah Sakit Umum Daerah Undata Palu dalam penanganan korban bencana Tahun 2012, Tim penanggulangan bencana rumah sakit sudah terbentuk namun tidak aktif, kesiapan SDM cukup namun fasilitas dan sarana penanganan korban bencana masih kurang serta SOP penanggulangan bencana masih kurang dan tidak adanya anggaran khusus untuk penanganan korban bencana.

Hasil penelitian ini tidak sejalan dengan hasil penelitian yang dilakukan oleh Hidayati (2008) yang menemukan bahwa terdapat hubungan yang signifikan antara Pengetahuan Perawat IRD RSUP DR. SARDJITO dalam Menghadapi Bencana pada Tahap Preparednes. Begitu juga dengan penelitian yang dilakukan oleh Gulton (2012) yang juga menemukan bahwa terdapat Pengaruh Pengetahuan Dan Sikap Terhadap Kesiapsiagaan Tenaga Kesehatan Puskesmas Kampung Baru Menghadapi Bencana Banjir Dikecamatan Medan Maimun.

\section{Kesimpulan}

Pengetahuan perawat di Instalasi Gawat Darurat Rumah Sakit Umum Majene tentang kesiapsiagaan menghadapi bencana lebih banyak pada kategori kurang. Kesiapsiagaan perawat di Instalasi Gawat Darurat Rumah Sakit Umum Majene dalam menghadapi bencana lebih banyak pada kategori kurang. Tidak terdapat Hubungan Pengetahuan perawat IRD dengan kesiapan menghadapi bencana di RSUD Majene tahun 2015.

\section{Daftar Pustaka}

Alex (2010). Psikologi Umum. Pustaka setia. Bandung.

Anam (2013), Faktor yang Mempengaruhi Kesiapsiagaan Perawat dalam Penanggulangan Bencana Gunung Kelur di Blita. PPS Program Studi Keperatan FK Universitas Brawijaya.http;//prodikeperawatanblitar .fil/.... diakses tanggal 4 April 2015.

AWHONN (2012), Association of Women's Health, Obstetric and Neonatal Nurses. Pada Anam (2013).

Baihaqi, (2005). Psikiatri (Konsep Dasar dan Gangguan-gangguan). Refika Aditama. Bandung.

BNPB. (2007). Penataan Ruang Kawasan Gunung Api. litbang.bnpb.go.id/.../. diaskes tanggal 5 April 2015.

BNPB (2010). Rencana Nasional Penanggulangan Bencana. litbang.bnpb.go.id/.../. diaskes tanggal 5 April 2015.

BNPB (2011). Perencanaan Kontijensi Menghadapi Bencana. Jakarta. litbang.bnpb.go.id/.../. diaskese tanggal 5 April 2015.

BPBD (2011), Data Bencana dan Korban Majene. Majene.

BPBD (2012), Data Bencana dan Korban Majene. Majene.

BPBD (2013), Data Bencana dan Korban Majene. Majene.

Brunner \& Suddarth. (2006). Keperawatan Medikal Bedah. Volume 1. EGC. Jakarta.

Depkes RI (2006). Pelayanan Instalasi Gawat Darurat. Depkes.go.id/.../... diakses tanggal 5 April 2015.

Departemen Kesehatan R.I (2006). Keputusan Menteri Kesehatan Nomor :066/MENKES/SK/11/2006, Pedoman 
Manajemen Sumber Daya Manusia (SDM) Kesehatan Dalam Penanggulangan Bencana. Depkes RI. Jakarta/

Dodon (2013), Indikator Dan Perilaku Kesiapsiagaan Masyarakat Di Permukiman Padat Penduduk Dalam Antisipasi Berbagai Fase Bencana Banjir.ITB.ejournal.unp.ac.id/students/i ndex... diakses tanggal 5 April 2015.

Effendi, N, (2008), Dasar - Dasar Keperawatan Kesehatan Masyarakat, Edisi 3. EGC. Jakarta.

Hidayat, A.,A.,A. (2010). Metode Penelitian Keperawatan dan teknik Analisis Data. Edisi 1.

Hidayati (2008). Pengetahuan Perawat IRD RSUP DR. SARDJITO dalam Mengahadapi Bencana pada Tahap Preparednes. FIK. UGM. Respiratory.ugm.ac.id/../.. diakses tanggal 5 April 2015.

Ismunandar (2012). Kesiapan Rumah Sakit Umum Daerah Undata Palu dalam penanganan korban bencana

Gie, T.L. (2008). Pengantar filsafat ilmu. Liberty. Jogjakarta.

Gulton (2012). Pengaruh Pengetahuan Dan Sikap Terhadap Kesiapsiagaan Tenaga Kesehatan Puskesmas Kampung Baru Menghadapi Bencana Banjir Dikecamatan Medan Maimun. PPS Kesmas USU. Respiratory.usu.ac.id/chapter.pdf. diakses tanggal 5 April 2015.

Kepmenkes 1653 tahun (2009). Pedoman Penanganan Bencana Bidang Kesehatan . Kemenkes.go.id./.././ diakses tanggal 5 April 2015.

Kogami, (2009) Modul Pengetahuan Menghadapi Bencana Alam. Padang Geoiogi.Fisik, Bandung; ITB.
LIPI-UNESCO/ISDR. $2006 . \quad$ Kajian Kesiapsiagaan Masyarakat dalam Mengantisipasi Bencana Gempa Bumi dan Tsunami. pada Anam (2013)

Lisnawati, NF (2010) Gambaran Kesiapsiagaan Perawat Puskesmas dalam Manajemen Bencana di Puskesmas Kasihan 1 Bantul Yogyakarta

Matsuda, Yoko., Okada, Norio. 2006. Community Diagnosis for Sustainable Disaster Preaparedness. Journal of Natural Disaster Science, Kyoto University, pada Anam (2013).

Mubarak, Wahit I. (2011). Promosi Kesehatan untuk Kebidanan. Salemba Medika. Jakarta.

Notoatmodjo, S. (2010). Metodologi Penelitian Kesehatan. Jakarta: Rineka Cipta.

Notoatmodjo S. (2011). Pendidikan dan perilaku kesehatan, Cetakan 2, PT. Rineka Cipta, Jakarta

Notoatmodjo S (2010). Promosi Kesehatan Teori dan Aplikasinya. Cetakan Kedua. Edisi Revisi. Jakarta :Rineka Cipta.

Price. 2008. Urban Flood Disaster Management. UNESCO-IHE, Delft

Sarim, Suhardi . (2003). Analisis Kesiapan Menghadapi Bencana di Instalasi Rawat Darurat Rumah Sakit Umum Daerah se-Wilayah pembangunan Cirebon

Sutton, J., and Tierney, K. (2006). Disaster Preparedness: Concepts, Guindance and Research. Colorado: University of Colorado. pada Anam (2013)

Soekanto, S. (2007). Sosiologi suatu pengantar. PT. Raja Grafindo Persada. Jakarta.

Sugiyono. (2011). Statistik Untuk Penelitian. Bandung: Alfabeta. 
Suhardjo, D.(2011). Arti Penting Pendidikan Mitigasi Bencana Dalam Mengurangi Resiko Bencana. 2.

Sunaryo. 2009. Psikologi Untuk Keperawatan. Penerbit Buku Kedokteran ECG: Jakarta.

Widyastuti (2006), Emergency Triage. Machester Triage Group. Pand Amerika Health Organitation. Edisi Terjemahan. Library.ui.go.id/.../dilihat pada tanggal 5 Juni 2015.

Takao, Kenji, Motoyoshi, Tadahiro, Sato, Teruko, Fukuzono, Teruki. (2004). Factors Determining Residents' Preparedness For Floods In Modern Megapolises: The Case Of The Tokai Flood Disaster In Japan. Journal of Risk Research, Carfax Publishing pada Anam (2013).

Undang-Undang No. 24 Tahun (2007) Tentang Penanggulangan Bencana

UN-ISDR. 2006. Living with Risk: A Global Review of Disaster Reduction Initiatives. Preapared as An InterAgency Effort Coordinated by the ISDR Secretariat with special support from the Government of Japan, the World Meteorological Organization and the Asian Disaster Reduction Center (Kobe, Japan). Geneva: ISDR Secretariat.pada Anam (2013). 